\title{
Theories of policy change and variation reconsidered: a prospectus for the political economy of public policy
}

\author{
Peter John ${ }^{1}$ (D)
}

Published online: 27 September 2017

(C) The Author(s) 2017. This article is an open access publication

\begin{abstract}
Studies of decision-making in public policy may be conceived as three distinct ages of theory building and testing. The first was the classic period of studies of decisionmaking and rationality; the second was the age of synthesis when theories of decisionmaking were blended into accounts of agenda setting. The third-which is starting to take shape-is the age of the political economy of public policy, drawing on models and methods that have been applied to the study of international relations and comparative politics, which are increasingly addressing issues in public policy. The paper's argument offers a challenge to public policy scholars to use theory and approaches from political economy and to integrate them with classic and synthetic approaches. Insights from public policy approaches from the first two ages could also inform the political economy of public policy. The paper contains a review of the development of public policy theory in the 1990s; it provides an account of the recent period as one of relative stability; it then presents work in comparative political economy as examples of research on public policy.
\end{abstract}

Keywords Public policy · Political economy $\cdot$ Decision-making

So far there have been two ages in the study of decision-making in public policy: the firstthe classic period-was when key terms were defined. Debates took place about the nature of decision-making and the extent to which full information prevails. It was the time when incrementalism, the rational model, the stages heuristic and sectoral representations of decision-making processes were elaborated, notably set out as the second two lens in Allison's influential Essence of Decision (1971). The second and synthetic age was of complex accounts of decision-making, which produced the policy advocacy coalition framework, the garbage can and policy window metaphors, and the punctuated equilibrium model - the currency of many of today's policy scholars. In these frameworks of analysis,

Peter John

peter.john@ucl.ac.uk

1 School of Public Policy, University College London, Gower Street, London WC1E 6BT, UK 
considerations about the nature of decision-making were blended into accounts of the influence of ideas and processes of agenda setting.

It is not clear whether the scholarly equilibrium produced by these works of synthesis is about to give way to a third age of public policy scholarship. The progress of normal science suggests such a development whereby empirical studies increasingly yield less novel findings (Kuhn 1970); then, there is the inevitable turning of the wheel as scholarship that was groundbreaking in the 1990s has itself become more routine, prompting the search for new models and approaches. The core argument of this paper is that innovative work is happening in public policy in a cognate sub-discipline. Even though the language and models are very different to those used in the first two ages, these studies use the same dependent variables as policy scholars - that is policy outputs and outcomes that vary across space and time. In the burgeoning arena of comparative political economy, scholars are producing a spate of works on public policy and it is striking that they do not usually cite classic works from the first two ages. ${ }^{1}$ The argument of this paper is that public policy scholars could embrace and take more advantage of research in this field because of the level of innovation that is taking place. Public policy studies could apply new tests of theories of policy change and variation and use of models that seek to attribute causal relationships rather than leaving them in a black box of multiple influences. In this way, work from comparative political economy can help address the key weakness of mainstream public policy studies, which is that it is hard to test the core claims because key terms often end up as descriptions or metaphors of policy changes rather than explanations of them. Such a field could be called the political economy of public policy. The direction of influence need not be one way, however, because studies in political economy tend not to take into account the detail of decision-making processes and the role of ideas and agenda setting. The third age could encompass models from economics and incorporate accounts of the policy process that appear in the classic and synthetic works in public policy.

\section{The first age: the classic works}

The key problem in public policy is to explain public decision-making: why do policies emerge and how do political actors seek to influence them, a theme that goes back to the earliest academic work in public policy, such as by Lasswell $(1951,1956)$. There are other questions in public policy, such as how to evaluate public policies, how to improve decision-making, and to understand implementation; but for policy scholars explaining policy choices is still the key problem to resolve and it is one that students of public policy get exposed to in their first weeks of study in a postgraduate course. This question influenced Herbert Simon (1955, 1997a, b), who stressed the limited range of decision-making choices that are considered and bounded rationality. Behind this work was an account of rational decision-making limited by norms and the cognitive capacity of human actors. Complementary work developed the incrementalist model of decision-making whereby decision-making process reflects a limited search for options, constrained by the cognitions of decision-makers and the influence of groups from within the bureaucracy (Lindblom 1959; Braybrooke and Lindblom 1963). These studies influenced contemporary work in the field, such as of budgeting (Wildavsky 1975). This foundational work, based on observing slow changes and standard operating procedures, also influenced studies of decision-

1 Examples of political economy papers that deal with decision-making, but do not cite public policy classics are Hays (2003), Plümper et al. (2008) and Plümper and Schneider (2009). 
making in policy sectors (Ripley and Franklin 1975, 1976). The literature on policy communities built on these classic studies by examining interrelationships between key actors, usually limiting policy options (Richardson and Jordan 1979), though sometimes with more variation and fluidity, as in policy networks (Heclo and Hugh 1978; Marsh et al. 1992). In addition, the literature on policy outputs stressed the constraining role of institutions and decision-making procedures (Dye 1966). Important—and also anticipating the agenda-setting approach of a later generation-was Hofferbert's (1974) funnel model of policy change, which shows how institutions and actors filter underling social forces when making policy. The key book of the classic age was-as referred to in the introductionAllison's (1971) with its schematic approach. Although this book discusses the rational model, it is clear its preference is for the bureaucratic and organizational process models of limited rational decision-making.

\section{The second age: synthetic approaches in public policy}

The underlying theme of much work in public policy in the 1990s is that change and variation emerges from the interaction of multiple factors, in particular from the salience of ideas, which had become more prominently discussed in series of publications in the 1980s (e.g. Stone 1989; Majone 1989). Scholars became more alert to the way in the policy agenda is constituted by new ideas and arguments, such as a new concept about the environment, or new evidence about the harm of certain human behaviours, such as tobacco use, from which rapid shifts in policy can result.

Kingdon's book, Agendas, Alternatives and Public Policies (1984), takes into account of the interplay of individual agents, ideas, institutions and external factors. Kingdon regards policy formation as the result of a flow of three sets of processes or streams: problems, policies and politics, which can come together in fortuitous circumstances called policy windows. The policy or multiple streams approach was a major step forward in understanding policy formation and inspired many other treatments (for example, Zahariadis 2003).

Sabatier's framework was also crucial innovation in theorizing. He and Jenkins-Smith synthesized many insights from classic accounts of public policy with the role of ideas in the formulation of public policies (Sabatier 1987, 1988; Sabatier and Jenkins-Smith 1993). In this framework, the advocacy coalition is an alliance of bodies holding the same ideas and interests with the purpose of arguing against other coalitions within the same sector. Knowledge plays a crucial role in defining these interests. The authors utilize Hofferbert's (1974) funnel model of policy innovation, an important book from the first age, to understand how policy issues are processed by many factors. Changes in economy and society feed into public opinion. This in turn affects the policy positions of political parties and interest groups and thence the ideas and preferences of policy makers. Since the publication of Policy Change and Learning: an Advocacy Coalition Approach, an extensive research programme has seen the mapping of coalitions (Weible et al. 2009), using quantitative and qualitative data (e.g. Sotirov and Memmler 2012), applied in many arenas, such as the European Union (Rozbicka 2013. Some authors have tried to deal with some of the limitations of the framework by integrating with other frameworks, such as cultural theory (Sotirov and Winkel 2016).

Similar in some respects to the policy streams and policy advocacy coalition (PAC) approaches is Baumgartner and Jones's (2009) punctuated equilibrium model of policy 
change as set out in Agendas and Instability in American Politics (2005), first published in 1993. Whereas traditional accounts of policy making emphasize the stability of decisionmaking in policy communities, other writers — such as Kingdon-stress continual change and adaptation. Instead, Baumgartner and Jones are interested in both change and stability. In a typical policy sector, there are long periods of stability followed by periods of public interest, media scrutiny and public action. Baumgartner and Jones are particularly interested in the rapidity of the change between periods of partial equilibrium and of issueexpansion, hence the idea that stable periods of policy making are punctuated by policy activism. The punctuated equilibrium model connects together in a dynamic framework the various elements to decision-making. Institutions are important because they freeze a set of political participants into the policy process and exclude others. Ideas, however, are vital. They are the building blocks of agendas. Baumgartner and Jones argue that policy-maker's cognitions and the institutional framework shape the way policy problems are defined.

Later work by Baumgartner and Jones elaborates the theoretical framework and tests for punctuated equilibrium (Jones and Baumgartner 2007), applied to a range of jurisdictions and time periods (e.g. Robinson et al. 2007; Mortensen 2005; Baumgartner et al. 2006). Recent work examines the precise nature of these institutional influences on policy punctuations (Epp and Baumgartner 2017) and the distribution of attention (Jones 2017). Scholars have been able to hypothesize the extent and range of punctuations in a less descriptive way than studies using the other two frameworks.

These elaborations of familiar frameworks are designed to show their similarities. Each is concerned to explain policy change just as much as policy stability, hence are interested in the way in which existing routines and interests are broken down in periods of change. They are preoccupied with the influence of ideas as much as institutions and interests. In expanding the range of causal inferences in public policy, they offer an account of the complex interactions between these multiple factors. They often use a concept to represent these influences, such as the advocacy coalition, policy window or punctuated equilibrium. These terms are simplifications or metaphors that convey key aspects of these complex policies, which have generated rich empirical programmes of work, whether tests of the stability of coalitions over time, case studies of the garbage can or tests of punctuated equilibrium. Hypotheses can be tested such as between degrees of leptokurtosis between venues in the punctuated equilibrium model and the impact of shocks on policy advocacy coalitions; but too many studies are descriptions of decision-making rather than offering causal explanation.

\section{The current state of policy studies}

Such has been the success of the three approaches highlighted above that they dominate the study of public policy. For example, Kingdon's (1984) book has received 13,803 citations in Google Scholar; Baumgartner and Jones (1993) get 5194 and Sabatier and JenkinsSmith have $3126 .^{2}$ The preponderance of citations is associated with a large number of case studies and research programmes, such as Comparative Policy Agendas (see Baumgartner et al. 2008). However, there have been few theoretical advances since the 1990s. New entrants have been happy to work with these frameworks, partly because of their ubiquity and they do not need that much adjustment to make them operate in different contexts. They provide a useful set of labels and concepts to motivate different kinds of study, such

${ }^{2}$ Checked with Google Scholar on 27 September 2015. 
as data collection and analysis, or case studies. Petridou's (2014) survey of recent work in public policy confirms this stable state of play, which does not to mean that there have not been other innovations, such as greater attention to the use of the comparative method in the study of public policy (Wilder 2017). There has also been an explosion of work on interpretative public policy, which has been growing in importance since Stone's (1989) influential essay on problem definition, in fields of post-positivist public policy (Fischer 2003, Fischer and Gottweiss 2012) and interpretivism (Yanow 1996), and empirical applications (see Griggs and Howarth 2011, McBeth et al. 2014). But such studies are not interested in explaining policy change in the sense of tracing the causal pathways.

The challenge is that topics in public policy are appearing in current debates in political economy. The next section contains an outline of this work to illustrate novel approaches to answering public policy questions, in spite of these studies not using the language and concepts from the first two ages of public policy. Then, the question emerges whether there can be a productive synthesis between the second and third ages.

\section{Comparative political economy}

One of the most significant intellectual developments of recent years has been the revival of interest in political economy, especially with a comparative range. This approach to study operates on two related dimensions: one is the role of the economy in structuring political choices (and also the influence of politics on economic outcomes); the other is about the method, which comes from economics, in theorizing about how political and economic variables relate together, often through formal models and/or advanced statistical methods. Political economy involves a closer relationship between the discipline of economics with its modelling and theory testing approach, and political science, which is more interested in contexts, the role of institutions, comparative systems design, and the influence of actors, such as voters and interest groups.

\section{Early work}

Economists have always been interested in politics, and the public choice revolution from the 1950s laid the foundations for the economic analysis of political institutions. The contribution of economic analysis to politics influenced the political theorist Brian Barry, most notably his Sociologists, Economists and Democracy (1970). More recently, Ostrom's $(1990,1998)$ work on Common Pool Resource (CPR) institutions had its origins in economic models, and it is notable that Ostrom won the Nobel prize for economics in 2009. This research programme continues to produce an extensive analysis of policy making, through more about the analysis of collective action failure and success rather than explaining decision-making (see Ostrom 2011). Political economy has influenced accounts of economic policy making, in particular the political-business cycle (Nordhaus 1975), which has seen contributions by economists and political scientists (e.g. Schultz 1995; Alesina et al. 1997). Economists have sought to understand why policy making departs from the standard model of efficiency, such as Dixit's (1996) account of trade policy, using a transactions costs framework. 


\section{The renaissance of political economy}

Economics and politics have cross-fertilized more strongly in recent years. Besley (2007) notes that articles on political economy only appeared in the top economic journals recently. In empirical analysis, economists have made the economy the dependent variable and examined the impact of politics. Work in political economy also has an interest in seeing politics and policy as the dependent variable, the object of explanation, so that the economy may be modelled into political choices as well as vice versa (Acemoglu and Robinson 2006). Economists have become interested in the impact of constitutions, voting in legislatures, representation and term limits - to name just a few topics. The interest from economics has stimulated political scientists either to model the relationships between key variables of interest, such as parties, voters, legislators, institutions and outcomes, or at least to heighten their interest in these issues. This line of work is characterized by attention to formal models, or at least care in specifying the causal relationships in advance, which are then implemented in statistical designs. This is of course not to say that mainstream public policy analysis has not used statistical methods, which appeared in early works in public policy, such as Dye's (1966) analysis of policy outputs. However, recent work is a step up in sophistication taking advantage of econometric work on time series and panel data (e.g. Plümper et al. 2005).

\section{The contribution of comparative political economy}

Comparative political economy is different from the long-running historical institutionalist approach to comparative public policy, whose adherents examined the impact of embedded practices on decision-making (see Hall 1986), though there are linkages in the varieties of capitalism debate (Hall and Soskice 2001), which seeks to understand how varied institutions in capitalism and associated regulation regimes affect the public policies, which in turn affects how the economy functions. In fact, any commentary on comparative political economy needs to acknowledge that scholars use the term quite permissively, ranging from the Marxian analyses of the working of the economy and politics (Blythe 1997), to the comparative study of political institutions alluded to above, to work on contrasts between developing and developed states (e.g. Evans 1989), as well as interdisciplinary work on politics and economics.

Scholars in comparative political economy seek to model relationships between politicians and economic power holders, which results in distinct policy choices. There is a complicated pattern of bargaining between these two actors, and between other power holders, such as bureaucrats. Of particular interest is the extent to which policy making is constrained by the bargaining between capital and labour. The key is to see how the universal constraint imposed by markets and capital interacts with contexts and institutions to produce different kinds of outcomes: the result might not necessarily show that economic power holders are always able to exercise their power (Dowding 1996). Franzese (2002: xviii) summarizes the approach:

similar policy-making challenges and universal tensions in the allocations of political resources in liberal market democracies induce different policies and outcomes because the domestic and international political- economic institutions, interest structures, and conditions within public and private actors operate and to which they respond to over time each factor interacts with the rest in shaping the incentives of strategic political-economic actors. 


\section{The debate about political institutions}

Much work in comparative political economy is focused on the impact of institutions upon the relationship between the economics and policy. Beramendi and Rueda (2007), for example, argue that the bargains between labour and the state, in the extent of corporatist arrangements, determine policy. They argue counter-intuitively that governments in corporatist countries have a weaker relationship to the market than other states. This relationship occurs because unions pre-commit to wage moderation and social peace in return for capital investment: because of capital mobility and the credibility of its exit threats to finance the welfare state, the state is structurally dependent on it and unions must accept so bearing much of the cost of the welfare state (2007: 627). States find it very hard to follow their preference for consumption taxes. In order to fund the welfare state, they have to tax labour. Such concerns speak to a wider political economy literature on the causes and consequences of inequality, which has an impact on policy choices (Lindert 1996; Barth et al. 2015).

The link between economic and institutions, and thence to policy, emerges in Cusack, Iversen and Soskice's work (Soskice and Iversen 1998; Cusack et al. 2010; Iversen and Soskice 2010). One puzzle is the choice of the electoral system: proportional representation helps to ensure more consensual policies on labour relations and training, and more egalitarian policies, but the choice of system is generated by the type of economy and employee relations in each country that encouraged it. Countries with a high degree of coordination choose more proportional systems, which generates different policy outcomes from countries with less cooperative industrial relations. The structure of political partiesand hence policies-depends on the economic system in play. Electoral systems feature in the work of Hicks (2015), on the impact on the concentration of left-wing votes. He shows that support for privatization policies may not be partisan.

\section{The importance of parties}

Work in comparative political economy uses statistical evidence to ascertain whether nation-states, and parties from the left when they are in power, can develop autonomous polices, such as social welfare, independent of the international market. Boix (2003) argues that parties of the left and right follow distinctive policies and that international trade competition does not impede these choices. Garrett (1998) argues that globalization does have an impact, but it causes left governments to invest more in the welfare state in order to counter the economic insecurity caused by globalization. Swank (2002) argues that institutions and political interests maintain their influence and ensure some autonomy over polices. Countries with strong welfare states can maintain them, and the effects of capital mobility are partial, affecting the smaller liberal welfare states rather than the larger ones that have a corporatist style of government. Rueda (2007) argues that parties may change over time and left parties do not always defend the working class. The argument is not that globalization does not exist, but that its effect is partial and mediated by political institutions. Moreover, Iversen and Cusack (2000) argue that domestically driven de-industrialization causes welfare expansion, showing no impact of globalization. Undermining Garrett's finding that globalization stimulates public spending, they find no relationship between a country's openness to trade and any measures of volatility. This literature shows that standard predictions from the power of the economic power holders do not necessarily hold when new data and models are applied. There is a wide and ongoing literature in the 
study of welfare states that addresses this core topic in political economy, which has policy implications (for reviews, see Häusermann et al. 2013; Potrafke 2016), where the more traditional literature on the impact of parties is giving way to one which looks at the complex interaction between electoral change and policy outputs.

\section{Convergence and globalization}

There is an established literature on whether policies have converged as a result of globalization, testing the race-to-the-bottom argument. One claim is that countries will not be able to tax mobile capital because it can jump ship, but a line of work in comparative political economy finds that this does not happen: countries carry on taxing (see review and test in Plümper et al. 2008). What constrains policy makers is a set of national factors, such as the size of the country, norms about fairness and budget constraints. Hays (2003) also finds convergence with the type of political institutions being important. There is no evidence for a race to the bottom in other policy fields, such as labour regulation and environmental standards. The extent to which policies are becoming more similar is questionable with some studies suggesting convergence, others not (see Plümper and Schneider 2009). Franzese and Hays (2008) find some evidence for interdependence for tax policy, but none for labour taxes. In this way, the work on comparative political economy meshes well with the long-running programme on the diffusion of policies, which started with work on the US states (Berry and Berry 1990), has become more theoretical in orientation (Shipan and Volden 2008), and has expanded to study international policies (e.g. Hays 2009; see also Graham et al. 2013; Gilardi 2010 for reviews), and examines the diffusion of policies between political parties (Böhmelt et al. 2016).

In much work in political economy, nation-states remain the powerful actors in determining international public policy, such as regulation standards (Drezner 2007). There is a wider commentary that suggests that political action-particularly at the international level-can counter the effects of globalization. Even writers on globalization claim that policy makers are not powerless in the face of global pressures and that they can introduce and implement some preferred policies. This is a common feature of theorizing where adherents of a perspective make their account more realistic by adding in features that address some common objections. This can be done in a model, such as Plümper et al. (2008); or more simply, Ha (2008) uses an institutional veto player model to examine the impact of globalization on welfare spending, by arguing that the number of veto players limited the ability of government to put these reforms into effect. This, in turn, links to Hays's (2003) finding about capital taxation. Nevertheless, even with these advances, it is hard to unpick the multi-causal nature of policy changes in advanced democracies (see the review by Zohlnhöfer et al. 2017).

\section{Sectoral studies}

The relationship between economics and politics can be explored in sectors, which relates to a long line of interest among policy scholars about the particular constraints on decisionmaking in functional fields, such as agriculture, education and so on. Ansell (2014) discusses the impact of valuation in housing on preferences, using the housing crash as a source of evidence. In a period of high house prices, it is possible that homeowners will become less supportive of social insurance policies because they see their houses as investments. This outcome provides an important link between the operation of markets and the structuring of political choices. Similar is Rehm (2011) who argues that public 
opinion in relationship to unemployment benefits is structured by the extent of inequality rather than being embedded preferences. Ansell and Lindvall's work shows the institutional drivers of differences in education policies across countries. Ansell's larger project (Ansell and Lindvall 2013; Ansell 2010; Ansell and Samuels 2015) is about how policy outcomes are structured by past partisan conflicts and competition between elites. Also, Stasavage examines electoral competition and public expenditure. Work on public opinion and education examines at segments of the population and their influence (e.g. Busemeyer 2012). Law and order appears in the work of Wenzelburger (2015), who tests for the impact of parties on public expenditure in this sector, which links to more general political economy work on morality policies (Knill 2013). Environment is an important topic which is getting more advanced treatment in comparative political perspective, and using methods common in comparative political economy, and is concerned to explain policy outputs and outcomes, such as meetings climate change targets or improving outcomes, either at the national state/international level (Ward 2006, 2008; Ward and Cao 2012) or at the city level (Portney and Berry 2013). These works ask fundamental questions about the limited relationship between democracy and the quality of policy outcomes.

More aligned to traditional work on interest groups and political power is Gilens and Page (2014) who are concerned with which kind of public has most influence on policy outcomes. Another piece of work is on the policy impact of health spending (Plümper and Neumayer 2013). Recent work has started to revive implementation studies with better data and models (e.g. Borghetto and Franchino 2010; Franchino and Mainentia 2016; McCann et al. 2015). There has been a more political economy turn to the long-running literature on distributive public policy, with sectoral studies appearing (Tepe and Vanhuysse 2013). In fact, one way to look at comparative political economy is to see it as a revival of interest in the structural determinants of politics, but with more advanced methods and formally derived theories.

\section{More developed theories}

One of the interesting developments is that papers appear either in economics or in political science journals, showing that economists and political scientists increasingly learn from each other, and the agenda is moving beyond looking at a policy dependent variable, but with political, economic, institutional, and policy variables included in a pattern of relationships. For example, Persson and Tabellini (2004) discuss how the electoral system structures welfare policy outcomes, and their earlier work looking at the determinants of public finance (Persson et al. 2000).

Studies are starting to emerge that use models from political economy and advanced statistical methods, seeking to make generalizations about the causes of policy outputs. The outcome variable is often the same as the ones that public policy scholars use, that is policy variation over time and place, but the mode of analysis and set of theories are different. In this way, accepted wisdoms from the literature can be tested and advances in theory made. Table 1 makes a summary of the main elements to this field, showing the implications for research. 
Table 1 Examples of policy topics used in comparative political economy

\begin{tabular}{|c|c|c|c|c|}
\hline Type of study & $\begin{array}{l}\text { Typical policy } \\
\text { outcome }\end{array}$ & Theory & Implications for research & Examples \\
\hline $\begin{array}{l}\text { Policy impact } \\
\text { of political } \\
\text { institutions }\end{array}$ & $\begin{array}{l}\text { Economic growth, } \\
\text { productivity }\end{array}$ & $\begin{array}{l}\text { Transactions costs, } \\
\text { coordination } \\
\text { advantages of } \\
\text { corporatism }\end{array}$ & $\begin{array}{l}\text { Cross-national studies, } \\
\text { both qualitative and } \\
\text { quantitative works }\end{array}$ & $\begin{array}{l}\text { Beramendi } \\
\text { and } \\
\text { Rueda } \\
\text { (2007) }\end{array}$ \\
\hline $\begin{array}{l}\text { The importance } \\
\text { of parties }\end{array}$ & $\begin{array}{l}\text { Economic growth, } \\
\text { welfare state } \\
\text { outputs }\end{array}$ & $\begin{array}{l}\text { Coordination of } \\
\text { electoral interests }\end{array}$ & $\begin{array}{l}\text { Cross-national studies, } \\
\text { both qualitative and } \\
\text { quantitative works }\end{array}$ & $\begin{array}{l}\text { Iversen and } \\
\text { Cusack } \\
(2000)\end{array}$ \\
\hline $\begin{array}{l}\text { Convergence } \\
\text { and } \\
\text { globalization }\end{array}$ & $\begin{array}{l}\text { Economic growth, } \\
\text { sectoral policy } \\
\text { outputs }\end{array}$ & $\begin{array}{l}\text { Exit threats and market } \\
\text { and competition }\end{array}$ & $\begin{array}{l}\text { Cross-national studies, } \\
\text { both qualitative and } \\
\text { quantitative works }\end{array}$ & $\begin{array}{l}\text { Plümper } \\
\text { et al. } \\
\text { (2008) }\end{array}$ \\
\hline $\begin{array}{l}\text { Sectoral studies } \\
\text { (education) }\end{array}$ & $\begin{array}{l}\text { Education } \\
\text { performance and } \\
\text { policies }\end{array}$ & $\begin{array}{l}\text { Functional pressures } \\
\text { and electoral } \\
\text { interests }\end{array}$ & $\begin{array}{l}\text { Detailed case studies, } \\
\text { statistical work within } \\
\text { and cross-nationally }\end{array}$ & $\begin{array}{l}\text { Ansell } \\
\text { (2014) }\end{array}$ \\
\hline $\begin{array}{r}\text { Sectoral studies } \\
\text { (environment) }\end{array}$ & $\begin{array}{l}\text { Policies to combat } \\
\text { climate change, } \\
\text { carbon reduction }\end{array}$ & $\begin{array}{l}\text { Institutional pressures } \\
\text { on policy, } \\
\text { democratic pressures }\end{array}$ & $\begin{array}{l}\text { Advanced cross-national } \\
\text { statistical work }\end{array}$ & $\begin{array}{l}\text { Ward and } \\
\text { Cao } \\
(2012)\end{array}$ \\
\hline
\end{tabular}

\section{Limitations of comparative political economy}

Comparative political economy can also be criticized too. It has tended to focus on a narrow range of questions that have come from the preoccupations of the founders, in particular examining the role of the state, private capital and trades unions, which are important topics but come from intellectual debates in the 1960s and 1970s, whereas currently there is thought to be a larger range of influences on policy choices and fragmentation of interests, a key insight of second age policy studies.

The other weakness is that in spite of advanced methods being used studies have not been infused by causal methods and natural experiments as is now common in large parts of economics and political science. There has been a revival in experimentation as a desired method of research, not just with randomized controlled trials, but in quasi-experiments or natural experiments that use the experimental design and methods to make inferences where the context satisfies the 'as if random' condition (Dunning 2012). Hence, the expansion of methods is difference-in-differences, regression discontinuity design, interrupted time series and propensity score matching as well as the analysis of randomized controlled trials (Angrist and Pischke 2008).

With the limitations attended to, it is possible that the field of the political economy of public policy could develop from where models would be prominent but would be seeking to explain a wider variety of outcomes and processes than in contemporary comparative political economy. Such a field would also connect with scholars working in more institutional fields, such as Congress, where the outcome variable is often public policies, even though the focus is on the operation of the institution to produce such policies (e.g. CanesWrone et al. 2008; Berry et al. 2010). 


\section{Synthesizing works in political economy and public policy}

Political economy can advance the classic topics of study in public policy, such as agenda setting. In the public policy investment framework (Bertelli and John 2013), an economic theory of investment is applied to decisions to pay attention to policy areas, where policy makers populate a portfolio to balance the risk and return from the public's responses to unanticipated events. By maximizing the portfolio return, governments can get re-elected. Such a project uses the data from the core of classic studies of public policy, but microfounds an argument for decisions to select policy topics on the government's agenda. That the findings of relative stability comport with qualitative understandings of the British policy process underlines the integration between political economy and more standard accounts of policy making. Further accounts of agenda setting use a theoretical model of why policies are preferred, such as Carpenter's (2002) work on Federal Drug Administration approval. It is possible to fuse formal models of agenda setting from Tsbeblis, which again is a political economy model that has policy predictions, with datasets on executive priorities that resemble more conventional public policy approaches. Kreppel and Oztas's (2017) study of EU Commission agenda setting is a case in point, which bridges these two studies. In general, public policy scholars are increasingly using literature from political economy (e.g. Green-Pedersen et al. 2017; Breunig et al. 2017; Jensen et al. 2016).

Political economy can reinvigorate the classic approaches. Not all concepts are usable, but there is potential. For example, Zohlnhöfer et al. (2015) and Herweg et al. (2015) breathe life into the multiple streams work with carefully posed hypotheses that can be applied to decision-making in political systems. Zohlnhöfer (2009) also provides an integrated model of policy change using the veto player model and linking it to the policy advocacy coalition framework.

\section{Conclusion: the third age of public policy?}

The argument of this paper is straightforward and may not prove to be controversial. Studies in public policy studies have proceeded along a path started by the founders who speculated on the reasons why policy varies in different places and times. Early writers drew on theories of decision-making, whether based on stages of the policy process driven by different external causes, or constraints on decision-making. Public policy scholars in the 1990s extended these concepts and models, adding in the salience of competing ideas as factors structuring public policy decisions. The three synthetic frameworks, which are closely linked, of multiple streams, policy advocacy coalitions, and the punctuated equilibrium model have been successful and will continue to be so with new elaborations and treatments, but the danger is that they have become insulated from developments in other academic arenas. They tend to suffer from a familiar problem of using description rather than explanation to understand change in complex decision-making environments. In contrast, comparative political economy is a fast-moving sub-discipline operating between economics and political science, which has expanded in recent years, and is engaging with debates in international relations and comparative politics, often examining policy outputs and outcomes.

A form of sorting may occur with scholars who are more interested in models and methods not engaging with the mainstream approaches in the study of public policy, and 
public policy scholars making few citations to works in comparative political economy. Innovations continue to be made to multiple streams and standard policy frameworks with new metaphors and models, such as Howlett et al's (2015) use of waving to describe policy change. But public policy has always been an integrative sub-discipline, and it is possible to envisage studies of the policy process influenced by comparative political economy appearing alongside and linked to the synthetic frameworks discussed above, perhaps adding micro-foundations and improved empirical tests. Comparative political economy studies of public policy could incorporate more complex understandings of the stages in the policy process, such as agenda setting and the influence of the media. Such concerns would characterize the political economy of public policy, whereby policy outputs are linked to economic constraints and the exigencies of democratic politics in its various forms. Such a project would enable the policy sciences once again to meet the interdisciplinary ambitions of its founders.

Acknowledgements The paper was first presented at the International Conference on Public Policy, Grenoble, 26-28 June 2013, Panel: New Directions in the Study of Public Policy, Session 1: 'New Directions: The State of the Art.' and then at the panel, 'The political science of public policy', held at the American Political Science Association meeting' San Francisco, 3-6 September 2015. I give thanks those who gave comments at the panels where the paper was presented, in particular to Guy Peters and Chris Hanretty. I also thank Fabrizo Gilardi and Tim Hicks for comments on an earlier version of the paper.

Open Access This article is distributed under the terms of the Creative Commons Attribution 4.0 International License (http://creativecommons.org/licenses/by/4.0/), which permits unrestricted use, distribution, and reproduction in any medium, provided you give appropriate credit to the original author(s) and the source, provide a link to the Creative Commons license, and indicate if changes were made.

\section{References}

Acemoglu, D., \& Robinson, J. A. (2006). Economic origins of dictatorship and democracy. Cambridge: Cambridge University Press.

Alesina, A., Roubini, N., \& Cohen, G. (1997). Political cycles and the macroeconomy. Cambridge, MA: MIT Press.

Allison, G. (1971). Essence of decision: Explaining the Cuban missile crisis. Boston: Little Brown.

Angrist, J., \& Pischke, J. S. (2008). Mostly harmless econometrics an empiricist's companion (1st ed.). Princeton: Princeton University Press.

Ansell, B. W. (2010). From the ballot to the blackboard: Redistributive political economy of education. New York: Cambridge University Press.

Ansell, B. W. (2014). The political economy of ownership: Housing markets and the welfare state. American Political Science Review, 108(2), 383-402.

Ansell, B. W., \& Lindvall, J. (2013). The political origins of primary education systems: Ideology, institutions, and interdenominational conflict in an era of nation-building. American Political Science Review, 107(3), 505-522.

Ansell, B. W., \& Samuels, D. (2015). Inequality and democratization: An Elite competition approach. Cambridge: Cambridge University Press.

Barry, B. (1970). Sociologists, economists, and democracy. Chicago: Chicago University Press.

Barth, E., Finseraas, H., \& Moene, K. O. (2015). Political reinforcement: How rising inequality curbs manifested welfare generosity. American Journal of Political Science, 59, 565-577.

Baumgartner, F. R., Foucault, M., \& Francois, Abel. (2006). Punctuated equilibrium in French budgeting processes. Journal of European Public Policy, 13(7), 1086-1103.

Baumgartner, F. R., Green-Pedersen, C., \& Jones, B. D. (Eds.). (2008). Comparative studies of policy agendas. Abingdon: Routledge.

Baumgartner, F. R., \& Jones, B. D. (1993). Agendas and instability in American politics. Chicago: University of Chicago Press. 
Baumgartner, F. R., \& Jones, B. D. (2009). Agendas and instability in American politics (2nd ed.). Chicago: The University of Chicago Press.

Beramendi, P., \& Rueda, D. (2007). Social democracy constrained: Indirect taxation in industrialized democracies. British Journal of Political Science, 37, 619-641.

Berry, F. S., \& Berry, W. D. (1990). State lottery adoptions as policy innovations: An event history analysis. American Political Science Review, 84, 395-415.

Berry, C., Burden, B., \& Howell, W. (2010). The president and the distribution of federal spending. American Political Science Review, 104, 783-799.

Bertelli, A., \& John, P. (2013). Public policy priority-setting and conditional representation in British statecraft. Oxford: Oxford University Press.

Besley, T. (2007). The new political economy. The Economic Journal, 117, 570-587.

Blythe, M. (1997). Any more bright ideas? The ideational turn of comparative political economy. Comparative Politics, 29, 229-250.

Böhmelt, T., Ezrow, L., Lehrer, R., \& Ward, H. (2016). Party policy diffusion. American Political Science Review, 110, 397-410.

Boix, C. (2003). Democracy and redistribution. Cambridge, UK: Cambridge University Press.

Borghetto, E., \& Franchino, F. (2010). The role of subnational authorities in the implementation of EU directives. Journal of European Public Policy, 17, 759-780.

Braybrooke, D., \& Lindblom, C. E. (1963). A strategy of decision: Policy evaluation as a social process. Glencoe: The Free Press of Glencoe.

Breunig, C., Lipsmeyer, C. S., \& Whitten, G. D. (2017). Introduction: Political budgeting from a comparative perspective. Journal of European Public Policy, 24, 6.

Busemeyer, M. R. (2012). Inequality and the political economy of education: An analysis of individual preferences in OECD countries. Journal of European Social Policy., 22, 219-240.

Canes-Wrone, B., Howell, W. G., \& Lewis, D. E. (2008). Executive influence in foreign versus domestic policy making: Toward a broader understanding of presidential power. Journal of Politics, 70, 1-16.

Carpenter, D. (2002). Groups the media agency waiting costs and FDA drug approval. American Journal of Political Science, 46(2), 490-505.

Cusack, T., Iversen, T., \& Soskice, D. (2010). Coevolution of capitalism and political representation: The choice of electoral systems. American Political Science Review, 104, 393-403.

Dixit, A. K. (1996). The making of economic policy. A transaction-cost politics perspective. Cambridge: MIT Press.

Dowding, K. (1996). Power. Milton Keynes: Open University Press.

Drezner, D. (2007). All politics is global: Explaining international regulatory regimes. Princeton: Princeton University Press.

Dunning, T. (2012). Natural experiments in the social sciences: A design-based approach. Strategies for social inquiry. Cambridge: Cambridge University Press.

Dye, T. R. (1966). Politics, economics, and the public: Policy outcomes in the American states. Chicago: Rand McNally.

Epp, D. A., \& Baumgartner, F. R. (2017). Complexity, capacity, and budget punctuations. Policy Studies Journal, 45, 247-264.

Evans, P. (1989). Predatory, developmental, and other apparatuses: A comparative political economy perspective on the third world state. Journal Sociological Forum, 4, 561-587.

Fischer, F. (2003). Reframing public policy: Discursive politics and deliberative practices. Oxford: Oxford University Press.

Fischer, F., \& Gottweiss, J. H. (Eds.). (2012). The argumentative turn revisited: Public policy as communicative practice. Durham, North Carolina: Duke University Press.

Franchino, F., \& Mainenti M. (2016). The electoral foundations to noncompliance: Addressing the puzzle of unlawful state aid in the European Union. Journal of Public Policy. Available on CJO2015.

Franzese, R. J. (2002). Macroeconomic policies of developed democracies. Cambridge, UK: Cambridge University Press.

Franzese, R., \& Hays, J. (2008). Interdependence in comparative politics: Substance, theory, empirics, substance. Comparative Political Studies, 41, 742-780.

Garrett, G. (1998). Partisan politics in the global economy. Cambridge, UK: Cambridge University Press.

Gilardi, F. (2010). Who learns from what in policy diffusion processes? American Journal of Political Science, 54(3), 650-666.

Gilens, M., \& Page, B. I. (2014). Testing theories of American politics: Elites, interest groups, and average citizens. Perspectives on Politics, 12, 564-581.

Graham, E. R., Shipan, C. R., \& Volden, C. (2013). The diffusion of policy diffusion research in political science. British Journal of Political Science, 43, 673-701. 
Green-Pedersen, C., Mortensen, P. B., \& Thesen, M. G. (2017). Incumbency bonus revisited: Causes and consequences of media dominance. British Journal of Political Science, 47(1), 131-148.

Griggs, S., \& Howarth, D. (2011). Discourse and practice: Using the power of well being. Bristol: Policy Press.

Ha, E. (2008). Globalization, veto players, and welfare spending. Comparative Political Studies, 41, 783-812.

Hall, P. A. (1986). Governing the economy: The politics of state intervention in Britain and France. Oxford: Polity.

Hall, P., \& Soskice, D. (Eds.). (2001). Varieties of capitalism: The institutional foundations of comparative advantage. Oxford: Oxford University Press.

Häusermann, S., Picot, G., \& Geering, D. (2013). Review article: Rethinking party politics and the welfare state-recent advances in the literature. British Journal of Political Science, 43, 221-240.

Hays, J. C. (2003). Globalization and capital taxation in consensus and majoritarian democracies. World Politics, 56, 79-113.

Hays, J. C. (2009). Globalization and the new politics of embedded liberalism. Oxford: Oxford University Press.

Heclo, H. (1978). Issue networks and the executive establishment. In A. King (Ed.), The new American political system (pp. 87-107). Washington, DC: American Enterprise Institute.

Herweg, N., Huß, C., \& Zohlnhöfer, R. (2015). Straightening the three streams: Theorising extensions of the multiple streams framework. European Journal Political Research, 54, 435-449.

Hicks, T. (2015). Acting right? Privatization, encompassing interests, and the left. Political Science Research \& Methods, 4, 427-448.

Hofferbert, R. I. (1974). The study of public policy. Indianapolis: Bobbs-Merrill.

Howlett, M., McConnell A., \& Perl A. (2015). Weaving the fabric of public policies: Comparing and integrating contemporary frameworks for the study of policy processes. Journal of Comparative Policy Analysis (early view).

Iversen, T., \& Cusack, T. R. (2000). The causes of welfare state expansion. De- industrialization or globalization? World Politics, 52, 313-349.

Iversen, T., \& Soskice, D. (2010). Real exchange rates and competitiveness: The political economy of skill formation, wage compression, and electoral systems. American Political Science Review, 104, $601-623$.

Jensen, J. L., Mortensen, P. B., \& Serritzlew, Søren. (2016). The dynamic model of choice for public policy reconsidered: A formal analysis with an application to US budget data. Journal of Public Administration Research and Theory, 26(2), 226-238.

Jones, B. (2017). Behavioral rationality as a foundation for public policy studies. Cognitive Systems Research, 43, 63-75.

Jones, B., \& Baumgartner, F. (2007). The politics of attention: How government prioritizes problems. Chicago: Chicago University Press.

Kingdon, J. W. (1984). Agendas, alternatives, and public policies. Boston: Little Brown.

Knill, C. (2013). The study of morality policy: analytical implications from a public policy perspective. Journal of European Public Policy, 20, 309-317.

Kreppel, A., Oztas B. (2017). Leading the band or just playing the tune? Reassessing the agenda-setting powers of the European commission. Comparative Political Studies (early view).

Kuhn, T. (1970). The structure of scientific revolutions. Chicago: University of Chicago Press.

Lasswell, H. D. (1951). The policy orientation. In D. Lerner \& H. D. Lasswell (Eds.), The policy sciences: Recent developments in scope and method. Stanford: Stanford University Press.

Lasswell, H. (1956). The decision process: Seven categories of functional analysis. College Park, MD: University of Maryland Press.

Lindblom, C. E. (1959). The science of 'muddling through'. Public Administration Review, 19, $79-88$.

Lindert, P. H. (1996). What limits social spending? Explorations in Economic History, 33, 1-34.

Majone, G. (1989). Evidence, argument, and persuasion in the policy process. New Haven: Yale University Press.

Marsh, D., \& Rhodes, R. A. W. (1992). Policy networks in British government. Oxford: Clarendon Press.

McBeth, M. C., Jones, M. D., \& Shanahan, E. A. (2014). The narrative policy framework. In P. A. Sabatier \& C. M. Weible (Eds.), Theories of the policy process (pp. 225-266). Boulder: Westview Press.

McCann, P. C., Shipan, C. R., \& Volden, C. (2015). Top-down federalism: State policy responses to national government discussions. Publius: The Journal of Federalism, 45, 495-525.

Mortensen, P. (2005). Policy punctuations in Danish local budgeting. Public Administration, 83(4), 931-950.

Nordhaus, W. (1975). The political business cycle. Review of Economic Studies, 42, 169-190. 
Ostrom, E. (1990). Governing the commons: The evolution of institutions for collective action. Cambridge, UK: Cambridge University Press.

Ostrom, E. (1998). A behavioral approach to the rational choice theory of collective action: Presidential address, American political science association, 1997. American Political Science Review, 92, 1-22.

Ostrom, E. (2011). Background on the institutional analysis and development framework. Policy Studies Journal, 39(1), 7-27.

Persson, T., Roland, G., \& Tabellini, G. (2000). Comparative politics and public finance. Journal of Political Economy, 108(6), 1121-1161.

Persson, T., \& Tabellini, G. (2004). Constitutional rules and fiscal policy outcomes. American Economic Review, 94(1), 25-45.

Petridou, E. (2014). Theories of the policy process: Contemporary scholarship and future directions. Policy Studies Journal, 42, 12-32.

Plümper, T., \& Neumayer, E. (2013). Health spending, out-of-pocket contributions, and mortality rates. Public Administration, 91, 403-418.

Plümper, T., \& Schneider, C. (2009). The analysis of policy convergence, or: How to chase a black cat in a dark room. Journal of European Public Policy, 16, 990-1011.

Plümper, T., Troeger, V. E., \& Manow, P. (2005). Panel data analysis in comparative politics: Linking method to theory. European Journal of Political Research, 44, 327-354.

Plümper, T., Troeger, V. E., \& Winner, H. (2008). Why is there no race to the bottom in capital taxation? International Studies Quarterly, 53, 761-786.

Portney, K. E., \& Berry, J. M. (2013). Civil society and sustainable cities. Comparative Political Studies, 47, 395-419.

Potrafke, N. (2016). Partisan politics: The empirical evidence from OECD panel studies. CESifo Working Paper Series No. 6024. Available at SSRN: https://ssrn.com/abstract=2829310.

Rehm, P. (2011). Social policy by popular demand. World Politics, 63, 271-299.

Richardson, J. J., \& Jordan, A. G. (1979). Governing under pressure: The policy process in a postparliamentary democracy. Oxford: Robertson.

Ripley, R. B., \& Franklin, G. A. (1975). Policy-making in the federal executive branch. New York: Free Press.

Ripley, R. B., \& Franklin, G. A. (1976). Congress, the bureaucracy, and public policy. Homewood, Ill.: Dorsey Press.

Robinson, S. E., Caver, F., Meier, K. J., \& O’Toole, L. J., Jr. (2007). Explaining policy punctuations: Bureaucratization and budget change. American Journal of Political Science, 51, 140-150.

Rozbicka, P. (2013). Advocacy coalitions: Influencing the policy process in the EU. Journal of European Public Policy, 20, 838-853.

Rueda, D. (2007). Social democracy inside out: Partisanship and labor market policy in advanced industrialized democracies. Oxford: Oxford University Press.

Sabatier, P. (1987). Knowledge, policy-oriented learning, and policy change. Science Communication, 8 , 649-692.

Sabatier, P. (1988). An advocacy coalition framework of policy change and the role of policy-oriented learning therein. Policy Sciences, 21(2/3), 129-168.

Sabatier, P. A., \& Jenkins-Smith, H. C. (1993). Policy change and learning: An Advocacy coalition approach. Boulder, Colo.: Westview Press.

Schultz, K. A. (1995). The politics of the political business cycle. British Journal of Political Science, 25, 79-99.

Shipan, C. R., \& Volden, C. (2008). The mechanisms of policy diffusion. American Journal of Political Science, 52, 840-857.

Simon, H. (1955). A behavioral model of rational choice. The Quarterly Journal of Economics, 69, 99-118.

Simon, H. (1997a). Administrative behavior (4th ed.). New York: Free Press.

Simon, H. (1997b). Models of bounded rationality: Empirically grounded economic reason (Vol. 3). Cambridge: The MIT Press.

Soskice, D., \& Iversen, T. (1998). Multiple wage-bargaining systems in the single European currency area. Oxford Review Economic Policy, 14, 110-124.

Sotirov, M., \& Memmler, M. (2012). The advocacy coalition framework in natural resource policy studiesrecent experiences and further prospects. Forest Policy and Economics, 16, 51-64.

Sotirov, M., \& Winkel, G. (2016). Toward a cognitive theory of shifting coalitions and policy change: Linking the advocacy coalition framework and cultural theory. Policy Sciences, 49(2), 125-154.

Stone, D. (1989). Causal stories and the formation of policy agendas. Political Science Quarterly, 104, 281-300. 
Swank, D. (2002). Global capital, political institutions, and policy change in developed welfare states. Cambridge: Cambridge University Press.

Tepe, M., \& Vanhuysse, P. (2013). Cops for hire? The political economy of police employment in the German states. Journal of Public Policy, 33, 165-199.

Ward, H. (2006). International linkages and environmental sustainability: The effectiveness of the regime and IGO networks. Journal of Peace Research, 43, 149-166.

Ward, H. (2008). Liberal democracy and sustainability. Environmental Politics, 17, 386-409.

Ward, H., \& Cao, X. (2012). Domestic and international influences on green taxation. Comparative Political Studies, 45, 1075-1103.

Weible, C., Sabatier, P., \& McQueen, K. (2009). Themes and variations: Taking stock of the advocacy coalition framework. Policy Studies Journal, 37, 121-140.

Wenzelburger, G. (2015). Parties, institutions, and the politics of law and order. British Journal of Political Science, 45(3), 663-687.

Wildavsky, A. B. (1975). Budgeting: A comparative theory of budgetary processes. Boston: Little, Brown.

Wilder, M. (2017). Comparative public policy: Origins, themes, new directions. Policy Studies Journal, 45, $47-66$.

Yanow, D. (1996). How does a policy mean?. Washington: Georgetown University Press.

Zahariadis, N. (2003). Ambiguity and choice in public policy: Political decision making in modern democracies. Washington, DC: Georgetown University Press.

Zohlnhöfer, R. (2009). How politics matter when policies change: Understanding policy change as a political problem. Journal of Comparative Policy Analysis: Research and Practice, 11, 97-115.

Zohlnhöfer, R., Engler, F., \& Dümig, K. (2017). The retreat of the interventionist state in advanced democracies. British Journal of Political Science. doi:10.1017/S0007123416000454.

Zohlnhöfer, R., Nicole, H., \& Rüb, F. (2015). Theoretically refining the multiple streams framework: An introduction. European Journal of Political Research, 54, 412-418. 